\title{
HYGIENIC RISK ASSESSMENT OF CHILDREN WITH SOMATIC HEALTH PROBLEMS ASSOCIATED WITH VITAMIN DEFICIENCY
}

\author{
0.J. Ustinova ${ }^{1,2}$, K.P. Luzhetskiy ${ }^{1,2}$, S.A. Valina ${ }^{1}$, Y.A. Ivashova ${ }^{1}$ \\ ${ }^{1}$ FBSI "Federal Scientific Center for Medical and Preventive Health Risk Management Technologies", Russian \\ Federation, Perm, 82 Monastyrskaya St., 614045 \\ ${ }^{2}$ FSBEI HPE "Perm State National Research University”, Russian Federation, Perm, 15 Bukireva St., 614990
}

A study of the seasonal provision of children attending pre-school organizations that implement the standard artificial diet fortification with vitamins $A, C, D, E, B 6$ and B12 was performed. It was found that 75-85 \% of children have a yearround vitamin deficiency and $40 \%$ cases have the status of polyhypovitaminose. In autumn and winter the provision of children with vitamins corresponds to the physiological needs, but in the spring months $70 \%$ of children have a deficit in vitamin C, and $15 \%$ - in vitamin A. Even in autumn, every third child has a deficiency in vitamin B6, and every tenth - in vitamin $D$; in the spring the number of children with insufficient provision of these vitamins increases in 1.8-6.3 times. Half of the children, who attend pre-school organizations, have year-round vitamin B12 deficiency. Vitamins deficiency of up to 3 times increases the risk of delayed physical development, children, and dysfunction processes of vascular tone regulation and autonomic reactivity, and the incidence of chronic diseases in children is 1.3-2.2 times higher.

Key words: children, pre-school organizations, vitamins, psychological and physical development and physical health of children

\section{Introduction}

Vitamins are important to optimal child growth and development [7, 9, 11]. However, scientific studies have reported a high incidence of hypovolemic hypotension among children in Russia [7, 13]. A dynamic study of the food status conducted by the Research Institute of Nutrition under the Russian Academy of Sciences has indicated insufficient consumption of Vitamin B, carotenoids, vitamin D, calcium, iron and iodine by children. The deficit of these microelements can be determined by their blood concentrations $[2,6,7]$. Regional studies have shown that the identified cases of deficit in Russia, as a rule, result from combined deficiency [6, 7, 10]. The Institute of Nutrition under the Russian Academy of Sciences also reports that no Russian children are provided with the vitamins to the full extent [7, 9, 13]. Recent multicenter studies have reported that vitamin $\mathrm{C}$ deficit is registered in $70-90 \%$ of children, vitamin B - in 20-90\% ( $\mathrm{B}_{2},-$ y $38 \%, \mathrm{~B}_{6}-$ y $64 \%$ ), beta-carotene - in more than $40 \%$, while $70 \%$ of children regardless of age, season, and residence have combined deficiency of three or more vitamins $[3,6,8,10]$. Even in summer, 35$70 \%$ of children are found to have insufficient supply of vitamins C, B1, B2, folic acid, and 20$40 \%$ of children have a deeper deficit of these microelements[6].

According to Article 14.21 of the Sanitary Regulations and Standards 2.4.1.3049-13 "Sanitary and Epidemiological Requirements to the Set-Up, Organization of, and Scheduling at Pre-School Educational Facilities" (PEF), in order to prevent microelement (vitamin and mineral substances) deficiency, "children's diet needs to include the food products enriched with micronutrients", or vitamin $\mathrm{C}$ needs to be artificially added [12]. It is believed that artificial vitamin $\mathrm{C}$ fortification of the children's diet at PEFs does not help fight polyvalent combined micronutrient deficiency 6,7 , $8]$.

The purpose of this research is to study the seasonal vitamin supply among the children at PEFs that implement artificial vitamin $\mathrm{C}$ fortification of the children's diet, and to identify the health disorders associated with the vitamin deficiency.

(c) Ustinova O.J., Luzhetskiy K.P., Valina S.A., Ivashova Y.A., 2015

Ustinova Olga Yurevna - MD, professor, Deputy director for medical work (e-mail: ustinova@fcrisk.ru; tel.: +7 (342) 236-32-64)

Luzhetskiy Konstantin Petrovich - PhD, Head of the clinic of ecology dependent and production-induced pathology (e-mail: nemo@ fcrisk.ru; tel.: +7 (342) 236-80-98).

Valina Svetlana Leonidovna - Allergist at the clinic of ecology dependent and production-induced pathology (e-mail: root@fcrisk.ru; tel.: +7 (342) 236-80-98).

Ivashova Julia Anatolevna - Head of the radiology department at the clinic of ecology dependent and production-induced pathology (e-mail: root@ fcrisk.ru; tel.: +7 (342) 237-27-92). 
Materials and Methods. An in-depth clinical and laboratory study of 188 children at two typical PEFs that implement artificial Vitamin $\mathrm{C}$ fortification of the children's diet was carried out to assess the seasonal vitamin supply and analyze the somatic health [3]. The surveyed children aged $5-6$, including $50.7 \%$ of girls and $49.3 \%$ of boys, had attended the PEF for at least 3 years. The clinical and laboratory studies were conducted in fall (September-October), winter (NovemberFebruary), and in spring (March-May).

In the course of the study, a number of sanitary and hygienic, epidemiological, clinical and laboratory methods were used. A sanitary and hygienic assessment of the dietary arrangements at PEFs was performed based on the laboratory studies conducted during scheduled inspections of pre-school educational facilities in 2012-2014, menu production records, product sheets, and brokerage journals at PEFs. The assessment of the real children's diet (volume of consumed food) and calculation of the vitamin supply were conducted during the field observations (social and hygienic monitoring sector). The assessment of the social status of children was conducted based on a medico-social survey with the use of a specially developed questionnaire. The questions served to collect information on per family member income, living conditions, parents' education, dietary pattern and food ration in the family, hereditary disorders, lifestyle (social risk analysis methods laboratory).

Epidemiological studies (a comparative retrospective morbidity analysis) was conducted based on the children's medical referrals in 2013 (data provided by the Compulsory Health Insurance Foundation).

In order to conduct a comparative assessment of the physical development and somatic health of the children with different vitamin supply, an indepth clinical and laboratory study of 126 children aged 5-6 was conducted at PEFs. The observation group included 100 children with polyvitamin deficiency that lasted for at least a year. The control group included the children with a physiological supply of the A, C, D, E, $\mathrm{B}_{6}$ and $\mathrm{B}_{12}$ vitamins throughout all the seasons under analysis. The groups were comparable in terms of gender, age, and social criteria. For the complete assessment of the somatic health in children, an indepth clinic-functional and instrumental study was conducted. It included exams by the following doctors: pediatrician, neurologist, gastroenterologist, ENT specialist, immunologist- allergist, as well as the following activities: anthropometry with the assessment of biological maturity of children dynamometer; measurement of blood pressure with the calculation the pulse pressure parameters, the average hemodynamic pressure; the assessment of the adaptive reserve of the cardiovascular system, the calculation of the index cardiac output; electrocardiography (ECG "Schiller AT-10 plus"), spirography (computer Spirograph "Schiller SP-10"), Rhinomanometry ("RhinoStream SRE2000 / 2100", RhinoMetrics), cardiointervalography (computer cardio software package "Poly-Spectrum"). The levels of vitamins $\mathrm{B}_{6}$ and $\mathrm{B}_{12}$ were tested with the help of a microbiological test combined with the colorimetric method (ID-Vit ${ }^{\circledR}$ Vitamin $B_{6}$ and «IDVit ${ }^{\circledR}$ Vitamin $B_{12}$, Immunodiagnostik AG, Germany). The level of vitamin $\mathrm{C}$ was measured with the help of Immunodiagnostik AG testkit, (Germany). The level of vitamins A, D and E were measured with the help of enzymoimmunoassay (Vitamin A, ИФА/Human Vitamin A, VA Elisa Kit, 96 CSB», CUSABIO BIOTECH, Co. Ltd., China; 25-OH Vitamin D, Euroimmune AG Germany; Vitamin E, IFA/Human Vitamin E, VE Elisa Kit, 96 CSB, CUSABIO BIOTECH, Co. Ltd., China) (ELx808IU absorbance microplate reader, Infinite F50 absorbance microplate reader).

The data processing was conducted with the use of variation frequency analysis with the account for Pearson's chi-square. The significance of the numerical values was measured with the help of Fisher's exact test and Student's test. The "vitamin blood level - negative effect marker" relationship was assessed by calculating the odds ratio and its confidence interval (CI). OR $\geq 1$ was used as the sign of a relationship [14].

Results and Discussion. Scheduled inspections at PEFs in 2012-2014, the analysis of the menu production records, and the data on the compliance with the developmental needs in nutrients and energy have shown that the sanitary and regulation standards 2.4.1.3049-13 concerning children's nutrition were followed thoroughly at the PEFs. However, the chemical content of individual dishes did not satisfy the physiological needs of children, as a rule, due to the violation of the cooking procedure which is a violation of Article 15.1 of the sanitary regulations and standards 2.4.1.3049-13. The analysis of the food basket used in children's nutrition at PEFs showed that a lot of different products were used in children's diet thus providing a balanced menu. The recommended volumes of consumed food, total energy, the content 
of proteins, fats and carbohydrates, as well as the vitamin (B1, B2, C) and mineral (C sanitary regulations and standards 2.4.1.3049-13a, Fe) supplies met the physiological needs of children while complying with the. However, the menu calculation showed that the levels of some products were exceeded: curds and curds products - by 3 times; fish, juices, fruits and vegetable s- by 1,4 times; sugar - by 1,7 times; the levels of some other products were insufficient: milk and dairy products (by 10\% lower than the recommended level). The field observations showed that the actual supply of children with proteins, fats and hydrocarbons as well as the total energy of the diet was by $20-30 \%$ lower than the calculated level $(\mathrm{p}=0.03)$ while the actual vitamin supply of the actual diet was lower than the calculated level by $20.1-20.9 \% \quad(\mathrm{p}=0.02)$. Still both indicators met the physiological standard $(\mathrm{p}=0.76)$.

The analysis of the social risk factors promoting vitamin deficiency showed that the families of $21-28 \%$ of children at the PEFs had the average monthly per capital income of maximum $10-12$ thousand roubles; $32-36 \%$ of the children consumed insufficient amount of vegetables and fruits, $23-28 \%$ had disbalanced menu, and 18-23\% had low physical activity $(\mathrm{p}=0,64-0,73)$.

The laboratory studies showed that the average group supply of vitamin $\mathrm{A}$ in all the analyzed seasons met the physiological norm $\left(0,13-0,51 \mu / \mathrm{c}^{3}\right)$ totaling $0,580-0,228 \mu / \mathrm{cm}^{3}(\mathrm{p}=0,89-0,62)$ (Table 1). At the same time, in September-may, the blood level of vitamin A decreased by 60,7\% ( $p \leq 0,003)$ : in fall and winter, the vitamin A level was within the norm in all the children, and in spring, it reached $0,116 \pm 0,006 \mu / \mathrm{cm}^{3}$ in $15 \%$ of the children which was significantly below the physiological standard $(\mathrm{p} \leq 0,001)$ (Table 2.).

The average group level of vitamin $\mathrm{E}$ in fall totaled $0,838 \pm 0,099 \mu \mathrm{mol} / \mathrm{dm}^{3}$ which satisfied the physiological standard $\left(0,15-0,87 \mu \mathrm{mol} / \mathrm{dm}^{3}\right.$, $\mathrm{p}=0,86)$. In fall and winter, the level decreased to $0,363-0,371 \mu \mathrm{mol} / \mathrm{dm}^{3} \quad(\mathrm{p} \leq 0,001)$ though stayed within the physiological standard $(\mathrm{p}=0,33-0,46)$ (Table1). Overall, the vitamin E supply in fall and winter decreased by $55,7-56,7 \% \quad(\mathrm{p} \leq 0,001 \quad$ as compared to fall).

In fall, the blood level of vitamin $\mathrm{C}$ in children totaled B $6,409 \pm 0,218 \mu / \mathrm{cm}^{3}$ thus approaching the lower limit of the physiological standard $(4,0-14,96$ $\left.\mu / \mathrm{cm}^{3}, p=0,09\right)$. In fall, the blood level of vitamin $C$ did not change significantly as compared to winter $\left(6,867 \pm 0,483 \mu / \mathrm{cm}^{3}\right)$, but in spring it went down by $24,7-29,8 \%(\mathrm{p} \leq 0,001)$ to $4,824 \pm 0,314 \mu / \mathrm{cm}^{3}$; at the same time, in $75 \%$ of children it did not exceed $2,875 \pm 0,229 \mu / \mathrm{cm}^{3}$ which was below the physiologically permissible level $(p \leq 0,001)$.

The results of a dynamic study of the vitamin D supply showed that its level in fall reached $34,493 \pm 1,422 \mathrm{ng} / \mathrm{cm}^{3}$ (standard $\left(30-100 \mathrm{ng} / \mathrm{cm}^{3}\right.$, $\mathrm{p}=0,67)$, however, in $11.1 \%$ of the children it did not exceed $26,540 \pm 1,303 \mathrm{ng} / \mathrm{cm}^{3}$ which was below the permissible level $(p \leq 0,001)$. In winter and spring, the vitamin D level decreased to $31,38-29,38$ $\mathrm{ng} / \mathrm{cm}^{3}(9,0-14,8 \%$ as compared to the fall indicator, $\mathrm{p}=0,06-0,26$ ), and the number of children with below the physiological supply increased by $4,6-6,3$ times (to 51,1-70\%; 23,70 $2,20 \mathrm{ng} / \mathrm{cm}^{3}$, $23,157 \pm 1,133 \mathrm{ng} / \mathrm{cm}^{3}$ respectively, $\mathrm{p} \leq 0,001-0,02$ ).

The average group levels of vitamin B6 did not undergo significant changes and met the norm $(4,6-$ $18,6 \mu \mathrm{g} / \mathrm{dm} 3)$ totaling in autumn $6,378 \pm 0,961 \mathrm{~g} /$ $\mathrm{dm} 3$, in winter $-7,815 \pm 2,137 \mu \mathrm{g} / \mathrm{dm} 3$ and $6,479 \pm$ $0,584 \mu \mathrm{g} / \mathrm{dm} 3$ in spring. However, if in autumn and winter, a low supply of vitamin B6 was detected in every third child $(33,3-31,6 \% 3,73-3,07 \mu \mathrm{g} / \mathrm{dm} 3$, respectively, $\mathrm{p}=0,02-0,01$ to the physiological standard), then in spring, the figure was at $60 \%(\mathrm{p}=$ $0,008-0,003)(3,459 \pm 0,201 \mu \mathrm{g} / \mathrm{dm} 3, \mathrm{p}=0.02)$.

The level of $\mathrm{B}_{12}$ in all the seasons under study did not undergo significant changes $(p=0,12-0,87)$ while approaching the lower limit of the standard (149-616 picomole/ $\left.\mathrm{dm}^{3}\right)$; in fall, it totaled $150,129 \pm 18,046$ picomole $/ \mathrm{dm}^{3}(\mathrm{p}=0,72)$, in winter $168,744 \pm 15,134$ picomole/ $\mathrm{dm}^{3}(\mathrm{p}=0,57)$ and in spring - 166,345 24,494 picomole $/ \mathrm{dm}^{3}(\mathrm{p}=0,68)$. However, $40-45 \%$ of the children had an insufficient supply of the vitamin all the year round. The vitamin level here did not exceed in fall $124,880 \pm 3,784$ picomole $/ \mathrm{dm}^{3}(\mathrm{p}=0,03)$, in winter $116,654 \pm 8,585$ picomole $/ \mathrm{dm}^{3}(\mathrm{p}=0,01)$, and in spring $-121,443 \pm 4,103$ picomole $/ \mathrm{dm}^{3}(\mathrm{p}=0,02)$ (Tables 1 and 2.).

The analysis of the seasonal vitamin supply of the children attending the PEFS that practice standard C-vitamin enrichment of the food ration showed that in September-October, the blood level of vitamins $\mathrm{A}, \mathrm{C}, \mathrm{D}, \mathrm{E}, \mathrm{B}_{6}$ and $\mathrm{B}_{12}$ conformed to the physiological standard in only $22.2 \%$ of the children, and even then it was at the lower boundary of the physiological standard. A selective deficit of one vitamin (as a rule vitamin $\mathrm{B}_{12}$ ), was registered in $37.8 \%$ of the children; a lack of several vitamins $\left(\mathrm{B}_{6}\right.$ and $\left.\mathrm{B}_{12}\right)$ was registered in $35.6 \%$ of the children, and the lack of vitamins $B_{12}$ and $D$ was registered in $6.7 \%$ of the children. Simultaneous deficiency of 3 or more vitamins was very rare: it was registered inly in $4.4 \%$ of the cases. 
Even in fall, one out of every 10 children (11.1\%) had vitamin D deficiency, every third child (33.3\%) had an insufficient supply of vitamin B6, and vitamin B12 deficiency was registered in half of the children (45\%). In winter (November-February), the blood levels of the analyzed vitamin corresponded to the lower border of the physiological standard in only $24.6 \%$ of the children (especially vitamins C, E, B6 and B12). Selective deficiency of one vitamin in winter was registered in $33.3 \%$ of the children (vitamin D - 14,0\%, B6 $7.0 \%, \mathrm{~B} 12-12.3 \%)$. The lack of two vitamins was registered in $36,8 \%$ (B6 and $\mathrm{B} 12-8.8 \%$ of children, vitamins $\mathrm{B} 12$ and $\mathrm{D}-$ in $17.5 \%, \mathrm{~B} 6$ and $\mathrm{D}-$ in $10.5 \%$ of the children). The cases of simultaneous low supply of three vitamins (B6, B12 and D) were very rare and registered only in $5.3 \%$ of the children. It should be noted that in winter, there was a 4.6 times increase in the number of children with the vitamin D deficiency (from $11.1 \%$ to $51.1 \%$, $r \leq 0,001$ ), but change the number of children with insufficient supply of vitamin B6 did not change significantly $(31,6 \%$ vs. $33.3 \%$ in fall, $\mathrm{p}=0.89)$ and vitamin $\mathrm{B} 12$ (40.7\% vs. $45 \%, \mathrm{p}=0.66)$. In spring (March-May), the number of children with the physiological level of the vitamins A, C, D, E, B6 and B12 supply does not exceed $15.6 \%$ (vs. 22,2$24,6 \%$ in the autumn-winter period, $\mathrm{p}=0,16-0,32$ ). Selective vitamin deficiency was registered in $32.2 \%$ of the children (vitamin D - 19,3\%, C - 9.2\%, B12 - 3.7\%), the lack of vitamins simultaneously in $36,8 \%$ (B6 and B12 - in $8.8 \%$, and vitamins B12 and $\mathrm{D}-$ in $17.5 \%$, and $\mathrm{B} 6$ and $\mathrm{D}-$ in $10.5 \%$ of the children). At the same time, $15.6 \%$ of the children had a simultaneous deficiency of three vitamins (B6, B12 and D - in $110 \%, \mathrm{~B} 6, \mathrm{~B} 12$, and $\mathrm{A}-$ in $0.9 \%$; C, A, and D - in 0,9\%, B6, B12; C - in 0.9\%; and $\mathrm{C}, \mathrm{D}$ and $\mathrm{B} 6$ - in 1.9\%). It should be noted that in spring, $5.5 \%$ of the children were registered to have a combined deficiency of four vitamins (A, D, B6 and B12 and C, D, B6 and B12), which was not registered in fall-winter. Overall, in spring, the children had a sufficient supply in only the vitamin E; $15 \%$ of the children had a deficit in vitamin A (in spring and winter - $0 \%, p=0,0003-0,02) ; 75 \%$ vitamin $\mathrm{C}$ (in spring and winter $-0 \% \mathrm{r} \leq 0,001) ; 70 \%$ - vitamin D (in spring and winter - 11,1-51,1\%, p = $0,02-0,001$ ); the number of children with a vitamin B6 deficiency increased more than two-fold $(60 \%)$ (in spring and winter - 33,3-31,6\%, $\mathrm{p}=0,003$ $0,008)$.

Table 1

The blood levels of vitamins in the children attending the PEFs that practice vitamin $\mathrm{C}$ enrichment

\begin{tabular}{|c|c|c|c|c|c|c|c|}
\hline \multirow{2}{*}{ Vitamins } & \multirow{2}{*}{$\begin{array}{l}\text { Physiological } \\
\text { standard }\end{array}$} & \multicolumn{3}{|c|}{ Season } & \multicolumn{3}{|c|}{$\begin{array}{l}\text { Significance of difference } \\
\text { between the groups } \\
(\mathrm{p} \leq 0,05)\end{array}$} \\
\hline & & $\begin{array}{c}\text { Fall } \\
\text { (September- } \\
\text { October) }\end{array}$ & $\begin{array}{c}\text { Winter } \\
\text { (November- } \\
\text { February) }\end{array}$ & $\begin{array}{c}\text { Spring } \\
\text { (March-May) }\end{array}$ & $p^{1}$ & $p^{2}$ & $p^{3}$ \\
\hline Vitamin A $(\mu \mathrm{g} / \mathrm{cm} 3)$ & $0,13-0,51$ & $0,580 \pm 0,033$ & $0,314 \pm 0,020$ & $0,228 \pm 0,020$ & $\leq 0,001$ & $\leq 0,001$ & $\leq 0,001$ \\
\hline Vitamin E (mcM /dm3) & $0,15-0,87$ & $0,838 \pm 0,099$ & $0,363 \pm 0,077$ & $0,371 \pm 0,033$ & $\leq 0,001$ & 0,85 & $\leq 0,001$ \\
\hline Vitamin C (mg/dm3) & $4,0-14,96$ & $6,409 \pm 0,218$ & $6,867 \pm 0,483$ & $4,824 \pm 0,314$ & 0,09 & $\leq 0,001$ & $\leq 0,001$ \\
\hline Vitamin D (ng/cm3) & $30-100$ & $34,493 \pm 1,422$ & $31,381 \pm 2,984$ & $29,386 \pm 1,911$ & 0,06 & 0,26 & $\leq 0,001$ \\
\hline Vitamin B6 $(\mu \mathrm{g} / \mathrm{dm} 3)$ & $4,6-18,6$ & $6,378 \pm 0,961$ & $7,815 \pm 2,137$ & $6,479 \pm 0,584$ & 0,22 & 0,23 & 0,86 \\
\hline $\begin{array}{c}\text { Vitamin B12 } \\
\text { (picomole/dm3) }\end{array}$ & 149-616 & $150,129 \pm 18,046$ & $\begin{array}{c}168,744 \pm \\
15,134\end{array}$ & $\begin{array}{c}166,345 \pm \\
24,494\end{array}$ & 0,12 & 0,87 & 0,29 \\
\hline
\end{tabular}

$\mathrm{N}$ o t e s : $p^{1}$ - the blood vitamin content in children in fall and winter; $p^{2}$ - the blood vitamin content in children in winter and spring;

$p^{3}$ - the blood vitamin content in children in spring and fall.

Table 2

The children with the blood level of vitamins below the physiological standard (\%)

\begin{tabular}{|c|c|c|c|c|c|c|c|}
\hline \multirow{2}{*}{ Vitamin } & \multirow{2}{*}{$\begin{array}{c}\text { Physiological } \\
\text { Standard }\end{array}$} & \multicolumn{3}{|c|}{ Season } & \multicolumn{3}{|c|}{$\begin{array}{c}\text { Significance of } \\
\text { difference between the } \\
\text { groups }(p \leq 0,05)\end{array}$} \\
\hline & & $\begin{array}{l}\text { Fall (September- } \\
\text { October)) }\end{array}$ & $\begin{array}{c}\text { Winter } \\
\text { (November- } \\
\text { February) } \\
\end{array}$ & $\begin{array}{c}\text { Spring } \\
\text { (March - } \\
\text { May) } \\
\end{array}$ & $p^{1}$ & $p^{2}$ & $p^{3}$ \\
\hline Vitamin $A(\mu \mathrm{g} / \mathrm{cm} 3)$ & $0,13-0,51$ & 0 & 0 & 15 & - & 0,02 & 0,000 \\
\hline
\end{tabular}


Hygienic risk assessment of children with somatic health problems ...

\begin{tabular}{|c|c|c|c|c|c|c|c|}
\hline & & & & & & 3 \\
\hline Vitamin E (mcM /dm3) & $0,15-0,87$ & 2,2 & 0 & 0 & 0,3 & - & 0,3 \\
\hline Vitamin C (мг/dm3) & $4,0-14,96$ & 0 & 0 & 75 & - & $\begin{array}{c}\leq 0,00 \\
1\end{array}$ & $\begin{array}{c}\leq 0,00 \\
1\end{array}$ \\
\hline Vitamin Д (ng/cm3) & $30-100$ & 11,1 & 51,1 & 70 & $\leq 0,00$ & 0,02 & $\begin{array}{c}\leq 0,00 \\
1\end{array}$ \\
\hline Vitamin B6 ( $\mathrm{gg} /$ дm3) & $4,6-18,6$ & 33,3 & 31,6 & 60 & 0,89 & 0,008 & 0,003 \\
\hline $\begin{array}{c}\text { Vitamin B12 } \\
\text { (picomole/dm3) }\end{array}$ & $149-616$ & 45 & 40,7 & 45 & 0,66 & 0,66 & - \\
\hline
\end{tabular}

$\mathrm{N}$ o t e s : $p^{1}-$ the blood vitamin content in fall and winter;

$p^{2}$ - the blood vitamin content in children in the fall and winter;

$p^{3}$ - the blood level of vitamins in spring and fall.

The results of an anthropomorphic study showed that the average group weight and height, chest circumference, and chest expansion during a deep breath, and carpal dynamometry in the children from the compared group corresponded to the age norm and did not have significant differences with them $(p=0,15-0,76)$. At the same time it was determined that the weight-related issues occurred 2 times more frequently in the group with a low vitamin supply as compared to the comparison group ( $29 \%$ vs. $15,4 \%, \mathrm{p}=0,03)$. The lack of weight occurred significantly more frequently ( $13 \%$ vs $3.9 \%, p=0.02$ ) while the excess of weight occurred in the both groups with a similar frequency $(16 \%$ vs. $11,5 \%, \mathrm{p}=0,59)$. The body mass index in the observation group $(15,48 \pm 0,36$ percentile) as well as in the comparison group $(15,18 \pm 0,62$ percentile) approached the lower limit of the physiological norm (15-18,5 percentile, $p=0,89-0,91)$. However the fraction of children with deviations from the standard value reached $42,7-32,6 \%$ respectively $(p=0,78)$. With that, there were $9 \%$ more children with the higher-than-usual values of this indicator in the observation group while there were no such children registered $(p=0,004)$. The relative risk of increased body mass index in the observation group was 1.56 times higher than in the comparison group $(\mathrm{OR}=1,28-2,34$; $\mathrm{DI}=1,05-3,47$; $\mathrm{p}=0,02)$. In every third case both in the observation group (31\%) and in the comparison group $(34,6 \%, p=0,74)$, the children's growth exceeded the standard level. At the same time, there were more children with a below-theaverage height in the group with a low vitamin supply (9\% против $3,9 \%, \mathrm{p}=0,04)$. Overall, the relative risk of weight-and-height disorders was 1,6-2,5 times higher in the observation group than in the comparison group (OR=2,28-2,50,0; $\mathrm{DI}=1,81-9,11 ; \mathrm{p}=0,03)$. Every third child in the observation group had a smaller chest circumference as compared to the age norm $(32 \%)$ while in the comparison group, the figure reached $19,2 \%(p=0,03)$. The calculation of the Erismann's index $[1,5]$ showed that both groups were dominated by children with disproportionate development, but negative Erismann's index indicating a sharp disharmonious development occurred in $76.8 \%$ of children in the observation group and only $54.2 \%$ in the comparison group (p $=0.03)$. The relative risk of the physical development of the children by the acutely disharmonious type was 2.8 times higher in the observation group $(\mathrm{OR}=2,79 ; \mathrm{DI}=2,11-6,23 ; \mathrm{p}$ $=0.04$ ).

The results of hand dynamometry in both girls and boys from the compared groups conformed to the lower limit of physiological standard (girls: 4.9-11.3 kg, boys: $6.1-13.4 \mathrm{~kg} ; \mathrm{p}=0.32-0.47)$ and did not differ from each other $(\mathrm{p}=0,15-0,63)$. At the same time, only in $51.7 \%$ of children with vitamin deficiency, the results of hand dynamometry conformed to the age norm while in the comparison group this indicator stood at $77.3 \%(p=0,03)$. The relative risk of a low muscle power in the children from the observation group was 3.2 times higher than in the comparison group $(\mathrm{OR}=3,21 ; \mathrm{DI}=2,02-7,81 ; \mathrm{p}=0,03)$.

A comparison of the biological maturity of the children was conducted based on the individual evaluation of the dental formula. The study showed that the dental formula in the majority of the children conformed to the age norm $(71.1 \%$ in the observation group, and $82.3 \%$ in the comparison group). However there were more children with delayed biological maturity in the observation group (27.9\%) than in the comparison group $(11,8 \%, \mathrm{p}=0,08)$. The relative risk of delayed biological maturity in the children from the observation group was 3.0 times higher $(\mathrm{OR}=3,0 ; \mathrm{DI}=1,11-1,96 ; \mathrm{p}=0,01)$.

Analysis of the arterial pressure showed that in both groups the systolic pressure $(95,45 \pm 3,59$ $\mathrm{mmHg}$ in the observation group; $94,78 \pm 3,72$ $\mathrm{mmHg}$ in the comparison group) and diastolic 
pressure $(62,66 \pm 3,66 \mathrm{mmHg}$ in the observation group and $61,11 \pm 3,68 \mathrm{mmHg}$ in the comparison group) did not differ significantly and conformed to $(\mathrm{p}=0,52-0,78)$ to the physiological age norm $(p=0,38-0,92)$. It should be noted that in half of the children in both the observation and comparison groups, the systolic pressure level was below the physiological norm at $85,71 \pm 7,01$ $\mathrm{mmHg}$ and $90,40 \pm 1,11 \mathrm{mmHg}$ respectively $(p=0,16)$. There were no children with the diastolic pressure below the physiological norm in the comparison group while that indicator reached $18,4 \%(p \leq 0,001)$ in the observation group. With that, the diastolic pressure level did not exceed $42,29 \pm 6,96 \mathrm{mmHg}$ ( $\mathrm{p} \leq 0,001$ to the physiological). Mean pulse pressure in the observation group totaled $33,53 \pm 2,97 \mathrm{mmHg}$ which did not differ from the comparison group at $33,80 \pm 2,94 \mathrm{mmHg}$ $(p=0,89)$. In both groups, however, the pressure was below the physiological $(p \leq 0,01)$. At the same time, in $26,3 \%$ of children in the comparison group, this indicator was below 30 $\mathrm{mmHg}$ which indirectly indicated the presence of a tendency to decreased cardiac output in every fourth child with vitamin deficiency while in the comparison group this indicator did not exceed $10 \%(\mathrm{p}=0,065)$. Overall, the relative risk of vascular control disorder in the children with vitamin deficiency was 3.3 times higher than in the comparison group $(\mathrm{OR}=3,27 ; \mathrm{DI}=2,11-7,41$; $\mathrm{p}=0,01)$.

Assessment of the mean hemodynamic arterial pressure in the systemic circulation, the pulse frequency, functional (adaptive) reserve of the cardiovascular system, minute volume and myocardial contractility did not reveal significant differences among the children from the compared groups ( $\mathrm{p}=0,32-0,94)$.

The study of excitability, conductivity and automatic performance of the cardiac muscle in the children with different vitamin supplies showed that malfunctions took place in more than half of the children from the both groups $(50.6 \%$ in the observation group, and $54.8 \%$ in the comparison group, $\mathrm{p}=0.67$ ). On the other hand, in the comparison group, the most frequent heart rhythm disorder was sinus tachycardia $(19,4 \%$, in the observation group $-7,2 \%, p=0,03$ ), and in the comparison group the most frequent disorders were sinus arrhythmia and brachycardia $(36,8 \%$ vs $22,6 \%$ in the comparison group, $p=0,005)$. The disorders affecting the conductivity of the cardiac muscle (incomplete block of the right bundle of atrioventricular bundle and intraventricular conduction disorder) were registered in $5.4 \%$ of the children in the observation group and in $3.2 \%$ of the children in the comparison group $(\mathrm{p}=0,02)$. Overall, the relative risk of disorders affecting the excitability and conductivity of the cardiac muscle in the children with vitamin deficiency was 2.1 times higher than in the children with a sufficient vitamin level $(\mathrm{OR}=2,08 ; \mathrm{DI}=1,14-4,21$; $\mathrm{p}=0,01)$.

An assessment of the functional condition of the children's respiratory system was conducted on the basis of a comparison of the chest expansion indicators at deep breathing, rhinomanometry, spirography, and oscillometry. The analysis of the range of chest expansion determined that the mean group value in the children with vitamin deficiency reached $4,7 \pm 0,4 \mathrm{~cm}$, and in the comparison group it reached $4,9 \pm 0,6 \mathrm{~cm}$, which was not significantly different either amongst themselves $(p=0,56)$ nor when compared with the physiological norm $(p=0,72-0,86)$. Equally, $43.8 \%$ of the children in the observation group had a low range of chest expansion (less than 4 $\mathrm{cm})$ while in the comparison group the value totaled only $20 \%(\mathrm{p}=0,05)$. The relative risk of the respiratory system disorders in the children with vitamin deficiency was more than 3.1 times higher as compared to the comparison group $(\mathrm{OR}=3,12 ; \mathrm{DI}=1,21-2,11 ; \mathrm{p}=0,04)$. The analysis of the functional condition of the upper respiratory system based on rhinomanometry showed that the total air flow volume in the children with vitamin deficiency reached $495,1 \pm 133,2 \mathrm{~cm}^{3} / \mathrm{s}$, which was not significantly different from the physiological norm (500-800 $\left.\mathrm{cm}^{3} / \mathrm{s} ; \mathrm{p}=0,77\right)$ and the comparison group $\left(435,3 \pm 156,3 \mathrm{~cm}^{3} / \mathrm{s} ; \quad \mathrm{p}=0,5\right)$. Nasal airway difficulties were registered in $79,6 \%$ of the children from the observation group and only in $46.2 \%$ of the children from the comparison group $(p=0,02)$. The relative risk of upper airway difficulties in the children with vitamin deficiency was 1.8 times higher than in the comparison group $(\mathrm{OR}=1,82 ; \mathrm{DI}=1,11-8,38 ; \mathrm{p}=0,02)$. The analysis of the functional condition of the lower respiratory system using spirography and impulse oscillometry showed that $9,6-10,3 \%$ of the children with vitamin deficiency had obstructive disorders while the children in the comparison group had the ventilation skills appropriate to the age norm $(\mathrm{p}=0,08-0,09)$. A comparative analysis of the functional condition of the vegetative 
nervous system was conducted using cardiointervalography and the calculated Kerdo index. The analysis results showed that amphotonic (50\%) was the prevailing type of the vegetative tonus; sympathicotonic type was diagnosed in $20 \%$ of the children, and vagotonic in $30 \%$ of the children. In the observation group, amphotonic and vagotonic types had the same occurrence as in the comparison group (50\% and $30 \%$ respectively), and sympathicotonic type was less frequent - only in $10 \%(\mathrm{p}=0,05)$. At the same time, hypersympathicotonic type of the initial vegetative tonus was registered in $10 \%$ of the children in this group and did not occur in the comparison group at all $(\mathrm{p}=0,001)$ indicating stressed adaptive mechanisms and decreased reserve abilities of the vegetative regulation (Table 3).

Table 3

Initial vegetative tonus in the children with a various level of vitamin supply (\%)

\begin{tabular}{|c|c|c|c|}
\hline \multirow{2}{*}{ Indicator } & \multicolumn{2}{|c|}{ Group } & \multirow{2}{\text{Significance}}{$\begin{array}{c}\text { of } \\
\text { differences } \\
\text { between the } \\
\text { groups } \\
(p \leq 0,05)\end{array}$} \\
\hline vagotonia & 30 & 30 & 0,98 \\
\hline Ayservation & $\begin{array}{c}\text { Comparison } \\
\text { group }\end{array}$ & 50 & 0,98 \\
\hline sympathicotonia & 50 & 20 & 0,05 \\
\hline hypersympathicotonia & 10 & 0 & 0,001 \\
\hline
\end{tabular}

A clino-orthostatic test revealed that hypersympathicotonic type was the prevailing type of vegetative response $(66,7 \%$ - observation group, and $60 \%$ - comparison group, $\mathrm{p}=0,33$ ) indicating stressed adaptive and compensatory mechanisms of body balance control and activation of the humoral and metabolic regulation, in addition to the vegetative. The physiological type of vegetative response - sympathicotonic response - was registered only in $33.3 \%$ of the observation group, and in $40 \%$ in the comparison group $(\mathrm{p}=0,33)$. The asympatico-tonic type of vegetative response characterized by zero stress of the adaptive and compensatory mechanisms was not registered in either of the groups. Mo which indicates the activity of the humoral arm of the vegetative regulation reached $0,67 \pm 0,06$ c.u., in the observation group, and $0,68 \pm 0,05$ c.u. in the comparison group thus significantly exceeding the physiological level $(\mathrm{p}=0,02-0,04)$, with no significant differences between the groups $(\mathrm{p}=0,77)$ (Table 4). Mode amplitude (AMo) which characterizes the stress of the sympatic regulation arm reached $33,1 \pm 9,2$ c.u. in the observation group, and $34,3 \pm 7,1$ c.u. in the comparison group which was significantly higher than the physiological norm $(p \leq 0,001)$, with no significant differences between the groups $(p=0,82)$.

The indicator of the condition of parasympathetic regulation component $(\mathrm{Dh})$ in the children from both groups exceeded the physiological norm at $0,41 \pm 0,09$ c.u. in the observation group, and $0,48 \pm 7,1$ c.u. in the comparison group ( $\mathrm{p} \leq 0,001$ to the norm), with no significant differences between the groups $(p=0,43)$. The stress index in the observation group $(77,9 \pm 5,8$ c.u.) tended to be higher than in the comparison group $(64,5 \pm 3,5$ c.u. $p=0,02)$. The study results indicated that the somatic state of the children from both groups was characterized by the stress of all the compensatory and adaptive mechanisms accompanied by the activation of the sympathetic and parasympathetic sectors of the vegetative nervous system, and the humoral and metabolic arm of the vegetative regulation. However, the integrated stress of the mechanisms responsible for homeostasis was higher in the children with vitamin deficiency (Table 4).

Table 4

Integrated indices of cardiointervalography that describe the state of vegetative regulation in children with different vitamin supply (c.u.)

\begin{tabular}{|c|c|c|c|c|c|c|}
\hline \multirow{2}{*}{ Index } & \multirow{2}{*}{ Physiological norm } & \multicolumn{2}{|c|}{ Group } & \multicolumn{3}{|c|}{ Significance of difference $(p \leq 0,05)$} \\
\cline { 3 - 7 } & & $\begin{array}{c}\text { Observation } \\
\text { group }\end{array}$ & Comparison group & $p^{1}$ & $p^{2}$ & $p^{3}$ \\
\hline Mo & $0,62 \pm 0,03$ & $0,67 \pm 0,06$ & $0,68 \pm 0,05$ & 0,02 & 0,04 & 0,77 \\
\hline Dh & $0,23 \pm 0,05$ & $0,41 \pm 0,09$ & $0,48 \pm 0,19$ & $\leq 0,001$ & $\leq 0,001$ & 0,43 \\
\hline AМо & $27 \pm 1,0$ & $33,1 \pm 9,2$ & $34,3 \pm 7,1$ & $\leq 0,001$ & $\leq 0,001$ & 0,82 \\
\hline ИН1 & $94 \pm 15$ & $77,9 \pm 5,8$ & $64,5 \pm 3,5$ & 0,11 & 0,28 & 0,02 \\
\hline
\end{tabular}

$\mathrm{N}$ o t e s : $p^{1}$ - significance of differences between the observation group and the physiological norm; $p^{2}$ - significance of differences between the comparison group and the physiological norm; 
$p^{3}$ - significance of differences between the observation group and the comparison group.

The incidence rate of chronic diseases in the children with different vitamin supply (\%)

\begin{tabular}{|c|c|c|c|c|}
\hline \multirow{2}{*}{$\begin{array}{l}\text { Groups of } \\
\text { disorders }\end{array}$} & \multirow[b]{2}{*}{ Nosological forms } & \multicolumn{2}{|c|}{ Group } & \multirow{2}{*}{$\begin{array}{c}\text { Significance of } \\
\text { differences between } \\
\text { the groups }\end{array}$} \\
\hline & & $\begin{array}{l}\text { Observation } \\
\text { group }\end{array}$ & $\begin{array}{l}\text { Comparison } \\
\text { group }\end{array}$ & \\
\hline \multicolumn{2}{|r|}{ Respiratory disorders (J00-J99) } & 61,0 & 37,5 & 0,03 \\
\hline & respiratory allergies $(\mathrm{J} 39.8)$ & 34,0 & 19,2 & 0,015 \\
\hline & Obstructive bronchitis (J44) & 10,0 & 0 & 0,04 \\
\hline \multicolumn{2}{|r|}{ Skin and skin structure disorders (L20-L92) } & 23,0 & 11,5 & 0,02 \\
\hline & atopic dermatitis (L20.8) & 23,0 & 11,5 & 0,02 \\
\hline \multicolumn{2}{|r|}{ Nervous disorders (G00-G99) } & 82,0 & 46,2 & $\leq 0,001$ \\
\hline & asthenoneurotic syndrome (G93.8) & 68,0 & 42,3 & 0,02 \\
\hline & Asthenic-vegetative syndrome (G90.8) & 28,0 & 15,4 & 0,03 \\
\hline \multicolumn{2}{|r|}{ Digestive disorders (K00-K93) } & 93,0 & 69,2 & 0,001 \\
\hline \multicolumn{2}{|c|}{ Musculoskeletal and collagen-vascular disorders (M00-M99) } & 74,0 & 42,3 & 0,002 \\
\hline & dorsopathy (M40-M54) & 34,0 & 23,1 & 0,04 \\
\hline & platypodia (M21.4) & 57,0 & 46,2 & 0,04 \\
\hline \multicolumn{2}{|c|}{$\begin{array}{l}\text { Blood and hematopoietic gland disorders, immune system disorders } \\
\text { (D50-D89) }\end{array}$} & 18,0 & 7,7 & 0,02 \\
\hline & Secondary transient immunodeficiency (D84.9) & 18,0 & 7,7 & 0,02 \\
\hline \multicolumn{2}{|c|}{ Endocrine, nutritional and metabolic disorders (E00-E99) } & 37,0 & 30,8 & 0,56 \\
\hline & Protein-energy malnutrition (E44.0-E44.1) & 15,0 & 7,7 & 0,03 \\
\hline
\end{tabular}

The results of the calculation of the Kerdo index confirmed the cardiointervalography results: positive Kerdo index in the observation group was registered in $90 \%$ of the children $28,19 \pm 4,59$ c.u. (in the comparison group $-100 \%$, $28,71 \pm 6,90$ c.u., $\mathrm{p}=0,15-0,90)$, which indicates a prevailing impact of the sympathetic component of the vegetative innervation in the adaptation and homeostasis support reactions physiologically common in the children of this age. At the same time, $10 \%$ of the children with vitamin deficiency had a negative Kerdo index while there were no negative indices revealed in the comparison group; this indicates an extreme stress and depletion of the adaptive reserve of vegetative regulation in these children.

A comparison of the prevalence of chronic somatic disorders in the children with different vitamin supply showed that chronic digestive tract disorders were the most common in the children from the compared groups $(93 \%$ - in the observation group, and и $69,2 \%$ - in the comparison group; $\mathrm{p}=0,001$ ), however the degree of their incidence in the children with low vitamin supply was 1.3 times higher than in the comparison group $(\mathrm{p}=0,001)$.

This category of disorders was manifested in the children from both groups mainly in the form of biliary dysfunction (MKB10-K83.8; 46\% observation group, and $42,3 \%$ - comparison group; $\mathrm{p}=0,74)$, and functional dyspepsia (MKB10-K30.0; 63\% - observation group, and
$53,9 \%$ - comparison group; $\mathrm{p}=0,74)$. It is noteworthy though that in the observation group, the frequency of combined pathologies (K83.8 and K30.0) was 1,9 times higher (44\% in the observation group, and $23,1 \%$ - in the comparison group; $p ; p=0,05)$. The relative risk of dysfunctional GT disorders in the children with poly-hypovitaminosis was 1.3-1.4 times higher than in the children with the physiological norm $(\mathrm{OR}=1,27-1,42 ; \quad \mathrm{DI}=1,09-3,16 ; \quad \mathrm{p}=0,02-0,04)$ (Table 5).

Chronic nervous disorders, mainly of the functional nature, were diagnosed in $82 \%$ of the children with vitamin deficiency, and in $46.2 \%$ of the children in the comparison group $(\mathrm{p} \leq 0,001)$, mostly in the form of asthenoneurotic syndrome (MKB10- G93.8; 68\% - in the observation group, and only $42,3 \%$ - in the comparison group; $\mathrm{p}=0,02$ ). Asthenovegetative syndrome (MKB10G90.8) was diagnosed in $28 \%$ of the children from the observation group, and only in $15.4 \%$ of the children in the comparison group $(\mathrm{p}=0,03)$. Enuresis (MKB10-F98), hyperactivity syndrome with attention deficit (MKB10-F90), and delayed mental development (MKB10-F88) had a similar rate of incidence in the groups $(3,9-12 \% ; \mathrm{p}=0,53$ $0,98)$. The relative risk of functional disorders of the nervous system in the children with polyhypovitaminosis was 2,0-3,0 times higher than in the children with satisfactory vitamin supply $(\mathrm{OR}=2,1-3,0 ; \mathrm{DI}=1,67-4,88 ; \mathrm{p}=0,01-0,03)$. 
As for chronic somatic diseases, respiratory disorders (MKB10-J00-J99) ranked third by being registered in $37.5 \%$ of the children in the comparison group, and $61 \%$ of children in the observation group $(\mathrm{p}=0,03)$. In the observation group, chronic respiratory diseases were manifested in the form of allergic conditions of upper respiratory system (MKB10-J39.8: allergic rhinitis, allergic rhinosinusitis, allergic laryngotracheitis, MKB10-J44: obstructive bronchitis) - $34 \%$, the incidence rate in the comparison group was 1.8 times lower $(19,2 \%$; $\mathrm{p}=0,015)$. Moreover, obstructive bronchitis (MKB10-J44) was diagnosed in $10 \%$ of the children in the observation group, and in the comparison group there were no children diagnosed with obstructive respiratory conditions $(p=0,04)$. The incidence rate of nasopharynx lymphoid hyperplasia was pretty high in both groups (MKB10-J35.1) (28\% - in the observation group, and $23,1 \%$ - in the comparison group; $\mathrm{p}=0,62)$; the incidence rate of chronic tonsillitis was lower (MKB10-J45.0) $(11 \%$ and $7,7 \%$ respectively; $\mathrm{p}=0,62)$.

Allergic skin reactions were also diagnosed quite frequently in the children with vitamin deficiency (MKB10- L20.8; 23\% - in the observation group, and $11,5 \%$ - in the comparison group; $\mathrm{p}=0,02)$. Simultaneous development of respiratory allergies and allergic skin reactions was found only in $19,2 \%$ of the children in the comparison group, and $42 \%$ of the children in the observation group $(p=0,05)$. The relative risk of respiratory disorders and allergic skin conditions in the children with polyhypovitaminosis was 2.12.3 times higher than in the children with the satisfactory vitamin level $(\mathrm{OR}=2,1-2,3$; $\mathrm{DI}=1,97$ 3,$16 ; \mathrm{p}=0,02$ ).

In the observation group, the incidence of musculoskeletal disorders and connective tissue conditions (MKB10-M00-M99) was almost twice as high $-74 \%$ and $42,3 \%$ respectively $(\mathrm{p}=0,002)$, and the incidence of the cases of combined pathology was higher (69\%) регистр: dorsopathy (MKB10-M40-M54) and platypodia (MKB10$\mathrm{M} 21.4$ ), and in the comparison group, this indicator was only at $34,6 \%(\mathrm{p}=0,001)$ (Table 5).
The relative risk of the locomotion disorders in the children with vitamin deficiency was 4.1 times higher than in the children with the physiological vitamin level $(\mathrm{OR}=4,1 ; \mathrm{DI}=2,21$ $6,18 ; p=0,001)$

In the course of the studies, it was also noted that the relative risk of chronic inflammatory UT diseases (N11.0-N39.0) and metabolic disorders (E66.9, E44.0-E44.1) in the children with vitamin deficiency than in the children with the physiological vitamin level $(p=0,04-0,05)$ (Table $5)$.

The analysis of the incidence rate of individual categories of chronic somatic pathologies showed that the relative risk of the GI, nervous, respiratory, musculoskeletal, and UT disorders in the children with vitamin deficiency was 1.3-2.4 times higher than in the children with the physiological vitamin level $(\mathrm{OR}=1,27-2,42$; $\mathrm{DI}=1,12-4,26 ; \mathrm{p}=0,02-0,04)$.

Conclusions. The results of the conducted integrated clinical and laboratory studies revealed that:

- 75-85\% of the children at PEFs have a year-round vitamin deficit, and $40 \%$ of them have polyhypovitaminosis;

- in September - May, the vitamin A level in children goes down by more than $60 \%$, vitamin $\mathrm{E}$ - by $55 \%$, vitamin $\mathrm{C}$ - by $25 \%$, vitamin $\mathrm{D}$ - by $15 \%$; the vitamin $\mathrm{B}_{6}$ and $\mathrm{B}_{12}$ levels are stable, and 40-45\% have year-round vitamin deficit;

- decreased vitamin levels in blood increases the risk vegetative response disorders by 2.5-3.3 times which can develop alongside stress of the vegetative-humoral mechanisms of homeostasis support;

- insufficient levels of vitamins A, C, D, B 6 and $\mathrm{B}_{12}$ increases the risk of delayed physical development, functional GI and nervous diseases, allergic respiratory and skin conditions, and locomotive disorders by 1.3-4.1 times;

- standard artificial C-vitamin enrichment of the food diet at PEFs does not prevent hypovitaminosis in $2 / 3$ of the children, and is combined in $45-70 \%$ of the children with low vitamins $B$ and $D$ levels.

\section{References}

1. Belikova R.M., Pyatunina O.I. Indeksy razvitija detej i podrostkov v uslovijah obuchenija sovremennoj shkoly [Indexes of children and teenagers development in the conditions of modern school education]. Uspehi sovremennogo estestvoznanija, 2008, no. 2, pp. 51-52. (in Russian). 
2. Gromova O.A., Namazova L.S. Vitaminy i mineraly v sovremennoj klinicheskoj medicine: vozmozhnosti lechebnyh i profilakticheskih tehnologij [Vitamins and minerals in modern clinical medicine: possibilities of therapeutic and preventive technologies]. Moscow, 2003, 56 p. (in Russian).

3. GOST-R 52379-2005 Nadlezhashhaja klinicheskaja praktika (ICH E6 GCP): Nacional'nyj standart RF (utv. prikazom Federal'nogo agentstva po tehnicheskomu regulirovaniju i metrologii ot 27 sentjabrja 2005 g. N 232st) [GOST-R 52379-2005 Proper clinical practice (ICH E6 GCP): National Standard of the Russian Federation (approved by the order of the Federal Agency for Technical Regulation and Metrology, September 27, 2005 N 232 - st)]. - M. - 2005. - 34 p. (in Russian).

4. Gromova O.A. Receptura vitaminnyh kompleksov, vospolnjajushhih fiziologicheskie potrebnosti v vitaminah u detej [Formulation of vitamin complexes, supplying physiological needs in vitamins in children]. Voprosy sovremennoj pediatrii, 2009, vol. 8, no. 6, pp. 77-84. (in Russian).

5. Evgrafova L.Je. Propedevtika v pediatrii. Metodika sbora anamneza i ob\#ektivnogo issledovanija rebenka [Propaedeutics in pediatrics. Methods of anamnesis and objective examination of a child]. Arhangel'sk: AMK, 2010, 83 p. (in Russian).

6. Kleshhina Ju.V., Eliseev Ju.Ju., Pavlov N.N. Osobennosti formirovanija narushenij pitanija u detej [Features of eating disorders in children]. Zdorov'e naselenija i sreda obitanija, 2012, no. 8 (233), pp. 20-22. (in Russian).

7. Kon' I.Ja. Deficit vitaminov u detej: osnovnye prichiny, formy i puti pro $\neg$ filaktiki u detej rannego i doshkol'nogo vozrasta [Vitamin deficiencies in children: the main causes, forms and ways of prevention in infants and preschool children]. Voprosy sovremennoj pediatrii, 2002, vol. 1, no. 2, pp. 62-66. (in Russian).

8. Kostantin Zh., Kugach V.V. Vitaminy i ih rol' v organizme [Vitamins and their role in the body]. Vestnik farmacii, 2006, no. 2 (32), pp. 58-70. (in Russian).

9. Kuchma V.R. Monitoring modernizacii organizacii pitanija detej v obrazovatel'nyh uchrezhdenijah [Monitoring of children catering modernization in educational institutions]. Zdorov'e naselenija $i$ sreda obitanija, 2012, no. 8 (233), pp. 7-10. (in Russian).

10. Zav'yalova A.N., Bulatova E.M., Vrzhesinskaja O.A., Isaeva V.A., Kodencova V.M., Pereverzeva O.G., Spirichev V.B., Ladodo O.B., Spiricheva T.V. Obespechennost' vitaminami i vozmozhnosti dieticheskoj korrekcii poligipovitaminoza u shkol'nikov Sankt-Peterburga [Provision with vitamins and dietary correction capabilities of polyhypovitaminosis of schoolchildren of St. Petersburg]. Gastrojenterologija Sankt-Peterburga, 2011, no. 4, pp. 35-39. (in Russian).

11. Rebrov V.G., Gromova O.A. Vitaminy, makro- i mikrojelementy [Gromova O.A. Vitamins, macro- and microelements]. Moscow: Gojetar-media, 2008, 954 p. (in Russian).

12. SanPiN 2.4.1.3049-13. Sanitarno-jepidemiologicheskie trebovanija k ustrojstvu, soderzhaniju i organizacii rezhima raboty doshkol'nyh obrazovatel'nyh organizacij. № 26 (zaregistrirovan v Ministerstve justicii Rossijskoj Federacii 29 maja 2013 goda, registracionnyj N 28564) [SanPiN 2.4.1.3049-13. Sanitary requirements for design, content and organization of the operation mode of preschool educational organizations. № 26 (registered in the Ministry of Justice of the Russian Federation, May 29, 2013, registration N is 28564)]. (in Russian).

13. Suetnova E.Ju., Setko N.P. Gigienicheskaja ocenka pitanija detej, poseshhajushhih detskoe doshkol'noe uchrezhdenie [Hygienic evaluation of nutritional status of children attending the day care center]. Zdorov'e naselenija i sreda obitanija, 2007, no. 2, pp. 27-29. (in Russian).

14. Fletcher R., Fletcher S., Vagner Je. Klinicheskaja jepidemiologija. Osnovy dokazatel'noj mediciny [Clinical epidemiology. Bases of evidence-based medicine]. Moscow: Media Sfera, 1998, 352 p. (in Russian). 